\title{
Parental Alienation in Divorce
} Judgments

\author{
Margit Gaffal \\ Universidad Pontificia de Comillas \\ Faculty of Humanities and Social Sciences
}




\begin{abstract}
${ }^{1}$
This paper deals with divorce judgments that were brought to Spanish Courts of Appeal between 2008 and 2011. In all the judgments parental alienation is mentioned as the grounds for appeal. Parental alienation is a pathologic family interaction that is often related to non-consensual divorce. In a systematic examination we will firstly, describe typical socio-economic characteristics under which parental separation takes place. According to these characteristics the decisions can be grouped into three types of conflict. Secondly, parent-child alienation will be explained as a problem that has minor and major consequences. Although parents do not normally opt for joint custody in non-consensual divorces, the law foresees it as a remedy to impede the aggravation of the alienation process.
\end{abstract}

En este trabajo se analizan las sentencias de divorcio que fueron resueltas en los tribunales españoles de apelación entre los años 2008 a 2011. En todas las sentencias se menciona como el motivo de la apelación la alienación parental. La alienación parental es una interacción patológica familiar que a menudo se relaciona con el divorcio no consensuado. En un estudio sistemático queremos describir, en primer lugar, las características socio-económicas típicas con que se lleva a cabo la separación entre los padres. De acuerdo a estas características las sentencias se pueden agrupar en tres tipos de conflictos. En segundo lugar, la alienación entre padres e hijos se explica como un problema que tiene una extensión y una estructura profunda. Aunque los padres no suelen optar por un régimen de custodia compartida en divorcios no consensuados, la ley lo prevé como un recurso para impedir un agravamiento del proceso de alienación.

Diese Arbeit ist eine Untersuchung von Berufungen gegen Scheidungsurteile, die im Zeitraum 2008 bis 2011 bei Spanischen Berufungsgerichten eingereicht wurden. In allen Berufungen wurde elterliche Entfremdung als Grund für die Berufung genannt. Die als elterliches Enfremdungssyndrom bekannte pathologische Interaktion tritt manchmal in Zusammenhang mit nicht-einvernehmlichen Scheidungen auf. In einem ersten Schritt werden die besonderen sozioökonomischen Bedingungen beschrieben, unter denen Scheidungen stattfinden. Die Scheidungsurteile können demnach in drei Gruppen eingeteilt werden. In einem nächsten Schritt wird elterliche Entfremdung als Konflikt analysiert, der eine Oberfächen- und eine Tiefenstruktur aufweist. Bei einvernehmlicher Scheidung sieht das Spanische Familienrecht die Möglichkeit eines gemeinsamen Sorgerechts der Eltern vor. Bei nicht-einvernehmlicher Scheidungen kann es vom Richter auf Antrag eines Elternteils zur Sicherstellung des Kindeswohl gewährt werden. In Fällen von elterlicher Entfremdung kann der Richter das gemeinsame Sorgerecht auch als Massnahme gegen eine Verschlimmerung des Entfremdungsprozesses verordnet werden.

Title: Parental Alienation in Divorce Judgments

Título: Alienación parental en sentencias de divorcio

Titel: Das elterliche Entfremdungssyndrom in Scheidungsurteilen

Keywords: divorce judgment, non-consensual divorce, appeal, child custody, parental alienation, the best interest of the child, family law

\footnotetext{
${ }^{1} \mathrm{C} /$ Universidad de Comillas, 3-5.

E-28049 Madrid, SPAIN.

Email: mgaffal@upcomillas.es
} 
Palabras clave: sentencia de divorcio, divorcio no consensuado, apelación, guarda y custodia, alienación parental, el interés del menor, derecho de familia

Stichwörter: Scheidungsurteil, nicht-einvernehmliche Scheidung, Berufung, Sorgerecht, elterliche Entfremdung, Kindeswohl, Familienrecht

\section{Summary}

1. Introduction

2. What is Parental Alienation?

3. Parental Alienation and Its Context

4. Joint Custody

5. Parental Alienation in Divorce Judgments

6. Parental Alienation before the ECHR

7. Conclusion

8. Table of Statutes and Cases

9. References 


\section{Introduction}

The disciplines of law and psychology have in common that they both address human behaviour $^{2}$. Whereas psychology intends to explain why people comport themselves in one or another way, the purpose of the law is to regulate human conduct. Both disciplines have been investigated extensively. There are, however, few studies that deal with the interaction between law and psychology ${ }^{3}$. In fact, legal terminology contains expressions and concepts from the field of psychology ${ }^{4}$. Therefore the results gained from psychological research may initiate improvements within a legal system. In the United States legal practitioners have become aware of the implications that psychological research may have for legal practice. In their daily work they are confronted with individuals who find themselves in conflicting situations to which they react in specific ways. The observer can make out recurring patterns of behaviour in these reactions. Leaving aside that human beings may act irrationally there seems to exist certain similarities within the conditions under which a conflict emerges, builds up and develops. Authors such as B. BROOKS-GORDON AND M. FREEMAN point to the manifold ways in which law and psychology are interrelated:

"It is not uncommon for law reviewers, particularly in the United States, to dedicate whole issues to questions of law and psychology. This is not surprising for psychology underpins many legal decisions and is at the root of many legal principles. To make some obvious examples, legal evidence may rest upon mental state or degree of harm, on issues of duress or trauma, or questions may arise as to the limits of provocation, as in the many notorious cases where battered women have killed violent husbands. Legal decisions may also depend upon predictions about future behaviour, (...)." (BROOKS-GORDON and FREEMAN, 2006, p. 1)

Psychological knowledge may help legal practitioners to understand the causal relations influencing human behaviour in times of dispute and tension. Insight into the dynamism of conflicts enables an expert to make suggestions for improvements concerning their legal advice to clients and legal proceedings. An interdisciplinary approach to the analysis of law requires the comprehension of multiple fields of science. As such it may turn out useful for judges to have some knowledge of home economics or social policy in order to deal with conflicts in many fields of civil law. A lawyer specializing in family law, for instance, may profit from background knowledge in developmental psychology when making decisions that affect children's lives. Basic knowledge on the nature and escalation of conflicts may also be helpful when dealing with marital conflicts.

\footnotetext{
${ }^{2}$ My special thanks go to two anonymous referees and their essential suggestions for improvement. The paper was revised during a research visit at the Bodleian Law Library at Oxford University in August 2012.

3 See BROOKS-GORDON and FREEMAN (2006).

4 "Fidelity, support" or "good faith" are relational concepts that are used in psychology as well as in civil law. Criminal law uses concepts such as "delinquency" or "fraud" both of which are forms of sociopathic disorders that have legal consequences.
} 


\section{What is Parental Alienation?}

This paper deals with non-consensual divorces of couples with children. We will analyze a sample of divorce judgments of appeal which revolve around the question of child custody. They have in common that one ex-spouse appealed against the judgment of the first instance requiring a change of the child custody regime. It is known that such custody disputes sometimes trigger off a process of alienation between the non-custodial parent and his or her child. From the psychological point of view such alienation jeopardizes the parent-child relation and is therefore difficult to treat. On the other hand, if the problem is disregarded and not acted upon, the conflict aggravates and consequently destroys the paternal relationship.

We are interested in this phenomenon because of its severity and irrevocable consequences. It is therefore justified to ask how the legal system deals with the problem and whether it foresees any solutions. Our analysis is based on the Spanish Civil Code and its provisions in Book I, title IV About Marriage, Chapter IX About the Effects of Divorce, Separation and Annulment and Title VII On Parent-Cild Relations. The Autonomous Communities of Catalonia, Valencia, Navarra, the Balearic Islands, the Basque Country, Galicia and Aragón have special foral laws that have principal validity over the Spanish Civil Code. We will make reference to those provisions of foral laws that concern our topic ${ }^{5}$. More specifically, we shall deal with the characteristic features of this alienation process. The following research questions are posed: What are the socioeconomic conditions under which disputes over child custody usually emerge? Is there a typical pattern according to which these characteristics are intertwined? How do Spanish courts deal with parental alienation? May a joint custody regime be a preventive measure against parental alienation? In order to answer these questions we shall examine both, the participants of the conflict and its intensification. The alienating parent's strategic steps are put in the context to his or her divorce-related goals.

We selected divorce judgments of the years 2008-2011 in which parental alienation was mentioned either as a central ground or an additional motive for appeal. A pre-selection of nine judgments served as the starting point for the investigation. These cases represent three types of judgments, the first standing for appeals that were rejected by the court, the second group represents appeals that were partly allowed and the third category represents appeals that were allowed $^{6}$. In a separate paragraph three cases of parental alienation caused by state authorities

\footnotetext{
5 See Code of the Foral Law of Aragón, Art. 80. Custody of Children, (BOA n. 63, of 29.3.2011); or Art. 5.2 of Act 5/2011, of 1 April, of the Regional Government of Valencia, on Family Relations Among Sons and Daughters Whose Parents Live Separately (BOE n. 98, sect. I, pp. 41873-41879).

6 The list of cases is: (rejected): SAP Albacete 12.12.2007 (JUR 2008\101505; MP: Manuel Mateos Rodríguez), SAP Madrid 19.10.2007 (JUR 2008\906; MP: Eladio Galán Cáceres), SAP Cádiz 5.9.2007 (JUR 2008\60961; MP: Ramón Romero Navarro); (partly allowed): SAP Barcelona 21.11.2007 (JUR 2008\30011; MP: Juan M. Jiménez de Parga Gastón), SAP A Coruña 31.3.2008 (JUR 2008\189828; MP: José Luis Seoane Spiegelberg), SAP Islas Baleares 12.3.2008 (JUR 2008\332743; MP: Juana María Gelabert Ferragut); (allowed): SAP Lugo 17.12.2007 (JUR 2008\81897; MP: $M^{a}$ Josefa Ruiz Tovar), SAP Vizcaya 27.3.2008 (JUR 2008\130045; MP: Nekane San Miguel Bergaretxe), SAP Toledo 23.3.2011 (JUR 2011\189719; MP: Urbano Suárez Sánchez).
} 
and prolongated legal proceedings and were brought before the European Court of Human Rights are examined.

In Spain parental alienation has become an influential factor in divorce processes in recent years. In the United States the phenomenon was noticed earlier and was first systematically described by R. Gardner in his recognized book "The Parental Alienation Syndrome, A Guide for Mental Health and Legal Professionals". The book found critical reflection in the research literature primarily among family therapists ${ }^{7}$. During his work as a forensic psychiatrist with divorcing couples he noticed repeated cases in which a discontented ex-spouse used psychological techniques to create a negative image of the other parent in the child. The aim was to gradually destroy the relationship between the child and his or her non-resident parent. R. GARDNER described the personality characteristics of the alienating parent and listed a series of typical symptoms in the affected children as a reaction to this process. These symptoms reflect the high level of hostility and reveal the disruptive impact that is involved in the conflict. The following table describes eight warning signs in children's conduct that serve as indicators of the syndrome:

\begin{tabular}{|l|l|}
\hline $\begin{array}{l}\text { Symptoms in child } \\
\text { conduct }\end{array}$ & Description \\
\hline $\begin{array}{l}\text { 1. Rejection, denigration } \\
\text { and defamation }\end{array}$ & $\begin{array}{l}\text { The child cannot remember happy times that he or she had with } \\
\text { his or her alienated parent. The child speaks disparagingly of the } \\
\text { parent and makes pejorative remarks. The child does not want to } \\
\text { visit or spend any time with the non-resident parent. The child } \\
\text { insults, shows disrespect, and humiliates the alienated parent often } \\
\text { in front of the alienating parent. }\end{array}$ \\
\hline $\begin{array}{l}\text { 2. Absurd } \\
\text { rationalization of } \\
\text { denigration }\end{array}$ & $\begin{array}{l}\text { If the child is asked for the reason of the denigration he or she } \\
\text { either cannot justify the accusations or gives absurd reasons and } \\
\text { holds irrational beliefs. }\end{array}$ \\
\hline $\begin{array}{l}\text { 3. Lack of normal } \\
\text { ambivalence }\end{array}$ & $\begin{array}{l}\text { In normal relationships between people there is always a certain } \\
\text { amount of ambivalence. There is always one or another aspect of } \\
\text { behaviour that is liked or not. Typical for the alienation is that } \\
\text { children lack any ambivalence in their feelings. They are often full } \\
\text { of hatred with no ability to see the positive side of the alienated } \\
\text { parent. }\end{array}$ \\
\hline $\begin{array}{l}\text { 4. Lack of independent } \\
\text { thinking }\end{array}$ & $\begin{array}{l}\text { Misleadingly, the alienating parent encourages the child to have an } \\
\text { opinion of his own. As a consequence three- or four-year-old } \\
\text { children state that it is their own opinion. }\end{array}$ \\
\hline $\begin{array}{l}\text { 5. Uncritical supporting } \\
\text { for the alienating parent }\end{array}$ & $\begin{array}{l}\text { Children tend to share the alienating parent's view without any } \\
\text { hesitancy or critical distance. The child tends to paraphrase } \\
\text { statements used by the alienating parent that sound untypical of } \\
\text { words likely to be used by a child. }\end{array}$ \\
\hline
\end{tabular}

7 See GARDNER (1986, 1994, 2002); BAKER (2005); HENDRICK (1994); SUMMERS, C. and SUMMERS, D. (2006); WALSH and BONE (1997); VASSILIOU and CARTWRIGHT (2001). 


\begin{tabular}{|l|l|}
\hline 6. Not feeling guilty & $\begin{array}{l}\text { They have no capacity of feeling guilty about how they behave } \\
\text { towards the alienated parent. On the contrary, children sometimes } \\
\text { say that it is the other parent's fault that they have no contact with } \\
\text { him or her. }\end{array}$ \\
\hline $\begin{array}{l}7 . \quad \text { Phenomenon of } \\
\text { 'borrowed scenarios' }\end{array}$ & $\begin{array}{l}\text { Children tend to report events and repeat accusations that come } \\
\text { from the alienator as if they came from themselves. }\end{array}$ \\
\hline $\begin{array}{l}\text { 8. Extension of } \\
\text { denigration to alienated } \\
\text { parent's family }\end{array}$ & $\begin{array}{l}\text { The children's negative attitude extends to the targeted parent's } \\
\text { extended family without any guilt or remorse. }\end{array}$ \\
\hline
\end{tabular}

Figure 1 (GARDNER, 2002, p. 26)

The reason why specialists speak of a syndrome is due to the observation that a range of typical signs tend to co-occur in this disorder. As such, an ex-spouse discontented with the post-divorce situation may intend to malign the other ex-spouse towards his or her child. To achieve such disaffection, the alienating parent uses explicit and implicit strategies to exert adverse influence on the relationship between the other parent and the child. The assumption that the phenomenon is a syndrome and not just an occasional and individual issue seems justified because of the prototypical signs that these conflict situations have in common. Studies have shown that the alienating parent not only uses recurring strategies but has also distinctive personality characteristics that make him or her susceptible to an aggravation of the conflict.

Although the pathologic family interaction follows a typical sequence it is not recognized as a disease according to the Diagnostic and Statistical Manual of Mental Disorders (DSM) for health professionals in the United States ${ }^{8}$. A proposal of a group of family therapists to include it in the forthcoming fifth edition of the DSM in 2013 is presently under study ${ }^{9}$. This proposal is also supported by the Spanish Association for Multidisciplinary Research on Parental Interference ${ }^{10}$.

In Spain recognition of the phenomenon has generated scientific discussion among experts mainly within the last five years ${ }^{11}$. Until the year 2005 approximately twenty judgments rendered by Spanish Provincial Courts contained an indication of parental alienation. In this context J. AGUiLAR CUENCA points to the lack of knowledge that professionals often have in the

8 See Diagnostic and Statistical Manual of Mental Disorders (DSM). For a review of this discussion confer JARNE ESPARCIA and ARCH MARÍN (2009, pp. 86-91).

9 See BERNET (2010).

10 See Asociación Española Multidisciplinar de Investigación sobre Interferencias Parentales (www.asemip.org).

11 See Aguilar Cuenca (2004); Alascio Carrasco (2008; Bermúdez Tapia (2009); Escudero (2008); Jarne EspaCia and Gómez Magan (2008); Segura (2006); SANchez Iglesias (2006); Tejedor Huerta (2007) and Vives Martínez (2007). 
understanding and treatment of this problem. He views this as the main problem when confronted with this phenomenon ${ }^{12}$.

The debate about the existence of the parental alienation syndrome is controversial, especially among legal scholars. Some experts deny its existence or consider the whole concept as unscientific whereas others recognize the concept but consider it irrelevant in the context of divorce. A profound investigation of arguments for and against the existence of PAS would go beyond the scope of this study. The focus of interest in this investigation is the question of how courts deal with it once a parent brings PAS to the judge`s attention. In this context, L. ALASCIO CARRASCO resumes that parental alienation is not new to Spanish courts but has played a minor role until now ${ }^{13}$. We shall examine the different modes in which family courts respond to this phenomenon. To understand the dynamism associated with parental alienation we shall describe the frame within which such pathologic interaction develops.

\section{Parental Alienation and Its Context}

From the legal perspective divorce is a courtroom event that follows a certain procedure. From the psychological point of view it is mostly preceded by a long process of dissociation of the spouses. Depending on who initiated the divorce it may cause a whole range of emotional reactions in the other spouse. This may involve feelings of confusion, sadness and the impression of losing control over one's life. It may even trigger off even more severe reactions such as depression, anxiety and an urge for revenge. Once the decision to divorce is communicated to the family members the children are basically involved in every phase of the separation.

The family transition is the phase between the separation and the actual divorce, which may last from six months to several years. Once the separation has been decided upon the spouses are requested to set up a regulating agreement (Art. $90 \mathrm{CC}$ ), in which they propose solutions on the following issues: parental authority, child custody and visiting regime for the non-resident parent (and grandparents), the attribution of the family accommodation and household equipment, contribution to matrimonial expenses and child payment, liquidation of economic matrimonial union and spousal support. The socio-economic changes which usually take place within this phase include (1) division of one household into two, (2) a change of living standards that affects both households, (3) requirement of the non-working ex-spouse to find a job and consequently (4) further education or job formation and (5) children's adaptation to the visitation regime with the non-resident parent. During this transition all family members have to reorganise their lives and adapt to the new circumstances. This is a demanding process and available mental resources when dealing with these problems depend mainly on organisation of family life prior to divorce.

\footnotetext{
12 See Aguilar Cuenca (2005, p. 79).

13 See ALASCIO CARRASCO (2008, p. 7).
} 
If the spouses do not arrive at a decision in their regulating agreement the court ruling applies (Arts. 91, 96 CC). Especially in non-consensual divorces the issue of child custody is a crucial question. Parental rights, such as, to have the children in one's company and take care of them, to represent them and to administrate their goods, is a fundamental right guaranteed under the concept of parental authority (patria potestad, Art. $154 \mathrm{CC})^{14}$. It is important here to distinguish between the fact that a parent is entitled to hold this fundamental right and the actual exercise of this right ${ }^{15}$. If parents have separated, parental authority is exercised by the one parent with whom the child resides (Art. 156. V CC). Should they fail to reach an agreement on the exercise of parental authority the judge will order a custody regime (Art. 159 CC). In this case the judge will hear the child's opinion and take his or her preference into account (Art. 770.4 ${ }^{\mathrm{a}}$ LEC).

If a parent is dissatisfied with the post-divorce situation he or she may use strategies of externalization to alleviate this discontent. He or she may view parental alienation as a means to achieve a more desirable solution. A way to achieve this is through projection in which the alienating parent transfers his or her negative attitude towards the other parent on to the child. The alienating parent denigrates the other parent in front of the child. The child, already alarmed by parental divorce, tends to be highly susceptible to the way in which both parents treat one another. It is only logical that the child feels dependent on the main caregiver because it is the person who satisfies his or her primary needs. As such the child is under the influence of the care-giving parent and forms an alliance with him or her. In this context it appears easy for the alienating parent to take advantage of this dependence by inciting the child to malign his or her absent parent.

In this context, some authors see parental alienation as a threat point of a parent to reach a certain end. Several authors observed that the appearance of parental alienation coincided with the implementation of joint custody as a preferable post-divorce parenting arrangement in the 1980s in the United States. They consider parental alienation an emotional disorder that appears primarily in the context of custody disputes. They argue, however, that Spanish courts have referred to parental alienation as a new clinical disorder which they consider of minor importance or rather as side effect of the promotion of joint custody ${ }^{16}$.

Undoubtedly, there are fundamental legal differences between the legal systems in the US and in Spain. In the United States the designation joint custody refers to two notions, that of joint legal custody and joint physical custody. Whereas joint legal custody implies that both parents hold parental authority, joint physical custody is a court-ordered schedule of alternating child care. In the United States a parent's proof of parental alienation is difficult and litigation may be interminable and expensive. In contrast, the Spanish legislation prohibits the alienating parent from interfering in the other parent's exercise of parental authority. If the alienated parent is

\footnotetext{
14 See Art. 39 Spanish Constitution.

15 See Montero Aroca (2002, p. 107).

16 See Escudero, Aguilar and de LA CRuz (2008, p. 285).
} 
cautious and reacts directly to first signs of parental alienation claiming his right of parental authority the alienating parent will face sanctions. Repeated infringement of the visiting regime may even result in a change of custody ${ }^{17}$. It is essential to intervene immediately because once the situation has deteriorated sharply it is difficult to intervene successfully.

Nevertheless, parental alienation and all its related symptoms are not always easily detected because its first symptoms are often hidden. As family relations are generally complex it is therefore useful for forensic psychologists to have special knowledge of its characteristics. An expert may notice some isolated symptoms but still disregard the systematic program of denigration as a whole SANCHEZ IGLESIAS underlines that parental alienation is frequently related to questions referring the visitation regime between non-custodial parent and child. He points out that first signs of alienation remain often undetected because legal professionals focus exclusively on the conflicting relationship between the ex-spouses:

"PAS is a very frequent phenomenon in cases of judicial incidents in processes of separation, especially related to the custody, and especially as refers the visitation regime. In order to detect the syndrome it is necessary to search beyond insidious actions that might conceal the disorder. Frequently, legal professionals such as judges and attorneys as well as psychologists and social workers inadvertently overlook the syndrome mainly they tend to put too much emphasize on a causal relation between alienating parent and the victim." (SANCHEZ IGLESIAS, 2006, p. 97)

A detailed analysis of the conflict shows that it consists of two levels, a "surface structure" and an underlying "deep structure". A parent's attempt to generate alienation takes place on the surface structure. But this is only an indicative of an underlying deeper problem. Its roots are situated in the socio-economic circumstances and the personality characteristics of the alienating parent, called deep structure ${ }^{18}$. We shall first describe the surface structure and then analyse possible grounds for the disorder in the deep structure.

The psychological dynamism that proceeds on the surface structure is some sort of "emotional kidnapping" of the child by the parent who wants to maximize the divorce-related gain. In this process the child assumes an unfortunate role. As the child's self-concept is bound to the caregiving parent, he or she aligns with this parent. In this identification with the alienating parent, the child takes over the parent's beliefs, values and behaviour. Psychoanalysis provides an interesting explanation for this emphatic process in the child interpreting it as the child's inevitable "identification with the aggressor". According to A. FREUD, the aim of such alliance is to cope with the anxiety that is produced by the aggressor's behaviour. At first sight this appears as a paradox reaction but is in fact a psychological defence mechanism that the "ego" activates in

\footnotetext{
17 See Law on Civil Procedure (Art. 776.3 LEC).

18 See GAFFAL (2010).
} 
the case of threat. It functions as a protection of the child's self against insuperable events. It can be compared to an "emergency break" that the ego uses to guarantee its functioning19.

Several psychological characteristics predispose a parent to become an initiator of parental alienation. For instance, there may be unresolved anger towards the ex-spouse and an inability to separate the role of the ex-spouse from that of a parent. There may be projections of onto the exspouse, especially concerning the relation to own parents. This leads to an egocentric view of divorce-related problems, impedes empathy and prevents a realistic view on the child's situation ${ }^{20}$. The alienating parent may have symbiotic tendencies in the relation to the child and thereby view the child's relationship to the other parent as a threat. In this context, C. SEGURA et.al. describe the typical alienating parent as a person lacking realistic self-assessment who has an inclination to symbiotic relationships. In the course of this process the alienating parent may develop more severe reactions such as a propensity for paranoia and pathogenic hatred towards the alienated parent ${ }^{21}$.

In this context, Gardner warned of the danger not to react in time to first symptoms of parental alienation. If the affected parent fails to do so the situation aggravates and results in a breakdown of the child-parent relationship. He pleads for an intervention of family judges in order to grant the child more time to spend with the alienated parent. Additionally the child should receive support from a therapist specialised in the treatment of the conflict. He warned of the inefficacy of traditional standard therapies in the case of parental alienation. He pleads for a therapist's authoritative approach and use of methods of confrontation in order to put pressure on the alienated parent. Only strict notification of the alienating parent can prevent further transgression of the divorce agreement and aggravation of the conflict.

The author also warned of the risks associated with long transition phases between the separation and the actual court decision. He resumes that family judges tend to avoid decisions that fundamentally change the child's life in the United States. They are usually hesitant to change custody regulations or reluctant to impose sanctions on the alienating parent. But this puts the alienating parent at an advantage and makes the consequences worse. Additionally, the child's constant rejection tends to demoralise the alienated parent. He advises the alienated parents to persevere in the effort to make and maintain contact with the child. The introduction of Law 15/2005 in Spain brought about an acceleration of divorce proceedings especially in nonconsensual divorces.

\footnotetext{
19 See FREUD (1993, p. 109f.).

20 See SuMMERS, C. and SuMMERS, D. (2006).

21 See SEgura, Gil and SEPUlveda (2006, p. 127).
} 


\section{Joint Custody}

The concept of custody (guarda y custodia) is inseparably linked to that of parental authority. Joint physical custody or refers to a parent-chosen and court-ordered schedule according to which the child stays with each parent at alternating intervals. Parents may agree on sole or joint exercise of their parental authority taking the best interest of the child into account (Art. 92.4 CC). Court decisions on custody take the preferences of parents and children into account as well as the family organisation prior to divorce. Generally there is a preference in most families to opt for maternal custody in the case of divorce. Likewise, judges attribute custody more frequently to mothers because they have more time available ${ }^{22}$. In respect of the best interest of the child the family accommodation is assigned to the child or children and the parent with whom they live (Art. 96 CC). The non-resident parent has the right to visit the children, communicate with them and have them in company (Art. $94 \mathrm{CC}$ ).

One of the aims of Law 15/2005 was to facilitate joint custody as a preferred post-divorce parenting option ${ }^{23}$. The introduction of joint custody as a preferred parenting option has given fathers the possibility of contributing more actively in post-divorce parenting. Among the motives for this reform was the introduction of the principle of parental co-responsibility in order to facilitate the reconciliation of work and private life. Joint custody may also be granted in nonconsensual divorces on a parent's request and upon a favorable report of the Public Prosecutor if this is to guarantee the best interest of the child (Art.92.8 CC). In this context the Civil Code of Aragón is explicit as it states that despite a parent's opposition against joint custody this may still be the best option to safeguard the best interest of the child (Art. 80.5) ${ }^{24}$. In the Autonomous Community of Valencia, Act 5/2011 foresees joint custody for both parents in non-consensual divorces as a general rule and states that a parent's opposition against joint custody or the parents' lack of consensus is no obstacle to this rule (Art. 5.2) ${ }^{25}$.

These legal provisions are in accordance with results obtained from psychological research results. Several authors have emphasized the importance of the child's maintaining a relationship to both parents after divorce. Especially long-term studies have underlined the importance of reliable relationships for a child's development of both, a positive self-concept and social competence ${ }^{26}$. The self-concept depends primarily on a successful identification with both parents provided that they themselves have self-esteem. This is a pre-requisite for a person's

\footnotetext{
22 See KeLLy (2005, p. 26f.).

${ }^{23}$ See Act 15/2005 of 8 July on the Modification of the Civil Code and the Law of Civil Procedure in the Field of Separation and Divorce.

24 See Artículo 80 Código Foral de Aragón. Guarda y custodia de los hijos.

25 See Ley 5/2011, de 1 abril, de las relaciones familiares de los hijos e hijas cuyos progenitores no conviven.

26 See WARTNER and GROSSMANN (1994).
} 
confident interaction with others. Additionally the presence of father and mother is important for a child's acquisition of gender role.

If we take into account that the father acts as a role model representing altogether nine sociological role-functions it becomes obvious that his absence produces a socialisation deficit. Studies on child custody revealed that children growing up in a joint custody setting show better results in terms of general adjustment, family relationships, self-esteem, emotional and behavioural adjustment, and divorce-specific adjustment ${ }^{27}$. Two studies on adjustment problems of children from divorced families appear relevant in this context. The first meta-analysis carried out by Keith and Amato pooled the results of 92 studies involving more than 13.000 children from pre-school to college age 28 . Their outcomes revealed that children in divorced families experienced more problems and had lower levels of well-being than children in continuously intact two parent families.

The second investigation, a long-term study carried out by Napp-Peters in 198029 , showed that constant absence of the non-resident parent causes irreversible psychological damage in the children. These outcomes are consistent with the hypothesis that joint custody is advantageous for children in emotional, behavioural and school-related respects. Special importance has the involvement with both parents, particularly the role that the father plays in the child's education. Each child has the right to maintain an independent relationship with each parent and to respect the individual differences in parenting styles and personal differences in each home. ${ }^{30}$

The type of custody regime is crucial in the regulation of parental post-divorce obligations. As such both ex-spouses have different starting positions from which they reorganize their postdivorce lives. The custodial parent remains in the family accommodation which creates the impression of continuity in a time of emotional turmoil. The non-custodial parent has to establish a new residence. The attribution of the family accommodation to the child and the custodial parent translates as an implicit form of spousal support. In fact, the economically more powerful ex-spouse has to cover mortgage rates of the family accommodation, child support, sometimes spousal support and the rent for a new residence. As a consequence many ex-spouses find this unsatisfactory if not unbearable, in cases in which financial obligations exceed the available income. As a reaction, some fathers make an appeal in which they claim joint custody in order to reduce their financial obligations.

\footnotetext{
27 See Amato and Gilbreth (1999, pp. 557 and ff.) and AmATO and KeITH (1991, p. 46).

28 See AMATO (1994, p. 145).

29 See NAPP-PETERS (1995).

30 See Guilarte Martin-Calero (2005, p. 113 and f.); Aquilino (2006, p. 929f.) and Arditti (1992, pp. 23-42).
} 


\section{Parental Alienation in Divorce Judgments}

Three divorce judgments of the year 2008 in which parental alienation was mentioned as the main criterion for the appeal are analysed. In the first case the appeal was rejected, in the second case it was partly allowed and in the third case the appeal was allowed.

The first case is an example in which parental alienation is a method to mask an underlying conflict and a strategic step to generate particular advantages. It may be an attempt to achieve a change of custody regime and child support payments. In the non-consensual divorce of SAP Albacete $^{31}$ a mother of three daughters accused her ex-husband of alienating their twin daughters from her. The couple got divorced two years before and the father had been attributed custody of the twin daughters who lived together in a rented flat. His ex-wife held custody of their third daughter with whom she remained in the family accommodation. Parental authority was maintained by both parents and visitation rights were mutually granted.

The father asked for a modification of the divorce judgment which stipulated that child support is to be paid reciprocally by both parents, except for the times at which all the daughters stayed together at one parent's place. The mother appealed against this judgment claiming custody of her two twin daughters arguing that they showed signs of rejection towards her. She diagnosed parental alienation, which -according to her view- had intentionally been initiated by her exhusband. A psychological test did not prove this hypothesis. She alleged lack of know-how in parental alienation and complained by questioning the psychologists' qualification to submit an expert opinion. At the same time she pleaded for a repetition of the test. The family judge responded literally that specialisation in PAS was not a necessary condition for the psychologists to render an expert assessment.

The psychological report eventually reasserted the absence of PAS. On the contrary, it contained evidence of the mother's authoritarian style and domineering behaviour in the education of her daughters. According to the report it was this conduct that had actually caused the daughters' rejection of her. The mother had also claimed for a recalculated reduction of her monthly child support payments for two daughters (650,- Euros) compared to her ex-husband's lower child support payment (225,- Euros). The judge held that the higher amount was justified because she had remained in the family accommodation whereas her ex-husband had to rent a flat. The mother's appeal was therefore rejected and no change was made to the regulating agreement. This case clearly shows the surface and deep structure of the conflict. Whereas the accusation of parental alienation happens on the surface structure the deep structure reveals two essential problems that the mother was confronted with, a psychological and a financial problem. The deep structure reveals that the daughters' repellent attitude was due to a problematic motherdaughter relationship. The mother intended to shift the blame for her daughters' rejection on her ex-husband with the aim of achieving a reduction of her child support payments.

31 See SAP Albacete 12.12.2007 (JUR 2008\101505; MP: Manuel Mateos Rodríguez). 
In SAP A Coruña ${ }^{32}$ the court attributed child custody to the mother and allowed an extensive visiting regime to father and child on alternating weekends including an additional visitation on one weekday afternoon. The father's obligation comprised child support payments until the daughter's economic independence. Payment of mortgage rates was equally distributed among both parents. In the father's subsequent appeal against this judgment he claimed custody of his daughter requesting dissolution of the matrimonial property regime concerning the family accommodation. The father also held that he had noticed signs of parental alienation in his daughter and asked for a psychological test. A test did not reveal any signs of PAS and concluded that although both parents basically could assume child-custody; maternal custody was considered the most appropriate regime for the child. This is expressed in the final judgment:

"Although the tests carried out lead to the conclusion that both parents could exercise custody of their daughter R., the mother is considered better suited to assume custody. Equally experts did not detect any signs of PAS, neither rejection against father visitation nor the mother's impeding these visitations." 33

As a reaction to the appeal the judge extended the visiting regime between father and daughter to two additional days instead of one. The decision entitled the ex-spouses to reach an agreement on the dissolution of the matrimonial property regime. However, this did not liberate each of them from paying half of the mortgage. Although divorce entails the dissolution of the matrimonial property regime, and each co-proprietor may ask for a division of the jointly owned property (Art. $400 \mathrm{CC}$ ), the principle of the best interest of the child establishes that such division must not put third persons at a disadvantage (Art. 405 CC). As such, the ex-spouses' agreement on the division of their jointly acquired property does not diminish the child's right to be attributed the family accommodation ${ }^{34}$. The judge responded to the father's claim by extending his visitation scheme.

In the third case of non-consensual divorce, SAP Lugo ${ }^{35}$ psychological assessment had revealed signs of parental alienation in the underage daughter towards her father. The father had appealed against the judgment of the first instance demanding a division of additional childrelated costs among both parents. According to the judgment of the first instance the father had to pay child support and mortgage rates despite of the fact that his ex-wife owned the flat. Therefore he asked for a reduction of child support payments and an equal distribution of mortgage rates. However, the appeal was rejected because of the mother's unemployment. The judge confirmed maternal custody provided that the daughter's rejection towards her father

\footnotetext{
32 See SAP A Coruña 31.3.2008 (JUR 2008\189828; MP: José Luis Seoane Spiegelberg).

33 See SAP A Coruña 31.3.2008 (JUR 2008\189828; MP: José Luis Seoane Spiegelberg).

34 See for a detailed discussion of the co-existence of the two legal norms confer FERNANDEZ CAMPOS (2008, p. 585).

${ }^{35}$ See SAP Lugo 17.12.2007 (JUR 2008\81897; MP: Mª Josefa Ruiz Tovar).
} 
would not deteriorate. As a preventive measure the father to daughter contact should be intensified. The judgment states this:

"Both, the exploration of the minor (categorical rejection of the father) and the psychological report advise that custody shall be maintained in the appeal, because a progression of visits has additionally been established. In neither of the parents any circumstance was observed that would advise against contacts of the minor with her father, nor that she continues living with her mother does not through that this one continues living with the mother (apparently the mother has another partner and having overcome her psychological problem of anxiety she seems suited to exercise custody of her child). The family counselling centre has observed unwillingness in the minor to meet her father, which is an indication of PAS. The visiting regime has been extended in the judgment and foresees a change of custody should the visiting regime not be respected."

It becomes obvious that in most cases of parental alienation there is a conflict over liabilities to pay. However, the provisions on parental authority ensure the right of both parents to maintain contact with their child. Even if parental authority is withdrawn from a parent for any serious reason, this parent is entitled to see the child. It is therefore legally forbidden to impede the relation between parent and child and between grandparents and child. If a parent repeatedly interferes with the other parent's right to contact his or her children, the Criminal Code foresees sanctions (Art. 618.2 CP).

In a similar case, SAP Toledo 36 , a mother of underage children infringed the law by impeding her children to visit their father. The father's appeal was allowed and his ex-wife was accused of misdemeanour being finally sanctioned to pay a penalty. In fact, the provisions of the Spanish Civil Code provide sufficient legal means to prevent parental alienation from further aggravation.

\section{Parental Alienation before the ECHR}

There are cases in which parental alienation was not caused by a parent but by a malfunctioning state authority. This is true for the following three cases brought up before high courts because of their degree of severity and insufficient solution on the national level. We shall exemplify three cases of parental alienation that were put before the European Court of Human Rights. In these cases the local authorities had failed to take effective measures to enforce the parent's right to maintain contact with the child.

In the first case Bordeianu v. Moldova ${ }^{37}$, a Moldavian citizen and mother of two minor children had got divorced in 2006. Despite of her right to maintain contact with her daughter it took eight

\footnotetext{
36 See SAP Toledo 23.3.2011 (JUR 2011 \189719; MP: Urbano Suárez Sánchez).

37 See Bordeianu v. Moldavia, TEDH C- 5/2011.
} 
months to produce the first encounter between mother and daughter. This long period of mother absence had produced parental alienation in the girl against her mother with the consequence that it was difficult to reestablish contact. The conflicting situation led to a delay of another four years without measures to establish regular mother to daughter meetings. Consequently, the mother sued the Moldavian authorities for violating her rights through omission and claimed her rights according the Convention on the Rights of the Child (Art. 8) ${ }^{38}$ that ensures the right to respect for private and family life. The European Court of Human Rights allowed the claim justifying the decision with the following words:

"The Court alludes that a judgment which sanctions breach of law implies, that the litigated State is legally obliged to put an end to this breach and to eliminate the consequences by reestablishing the situation according to how it had existed before the breach. (...) The Court is of the opinion that the appellant has suffered considerable damage, taking into consideration the circumstances of the case, the particular lack of diligence of local authorities and the fact that the appellant has still no contact to her daughter. A mere admission of guilt is therefore no sufficient means to compensate the damage sustained. Under these special circumstances the Court considers appropriate to award damages of 10.000 EUR to the party."

In a similar case of Mincheva $v$. Bulgaria39, a mother was not able to see her son for two years due to the father's resistance. She filed a suit because of the lack of remedy by which to bring up her complaint under Bulgarian law and the delay of custody proceedings. She accused the local authorities of having failed to enforce her right to contact to her child making as well reference to Convention on the Rights of the Child. Article 8 of the Convention states the following:

"1. States Parties undertake to respect the right of the child to preserve his or her identity, including nationality, name and family relations as recognized by law without unlawful interference.

2. Where a child is illegally deprived of some or all of the elements of his or her identity, States Parties shall provide appropriate assistance and protection, with a view to reestablishing speedily his or her identity."

In his final judgment the European Court of Human Rights confirmed the mother's right and she consequently received damages.

In the third case Piazzi v. Italy ${ }^{40}$, a failure of the social services to ensure that court decisions were complied with, prevented an Italian citizen from seeing his son for a period of seven years. This had produced parental alienation in the child with consequences that were difficult to make

\footnotetext{
38 See Convention on the Rights of the Child.

${ }^{39}$ See Mincheva v. Bulgaria, TEDH C- 91/2010.

${ }^{40}$ See Piazzi v. Italy, TEDH C-360648/2010.
} 
good. The applicant accused the services of omission in the administration of court decisions referring to the same legislation as mentioned in the other two cases and was finally granted damages.

An analysis of the respective national civil codes of the cases mentioned would go beyond the scope of this study. The cases reveal, however, that incorrect or deficient enactment of legal provisions or lacunae en procedural law may cause parental alienation in children whose parents undergo a of divorce.

\section{Conclusion}

The phenomenon of parental alienation is relatively new in Spain and tends to occur in nonconsensual divorces. The divorce judgments of appeal studied in this article reveal the complexity of the conflicts that prevail among the ex-spouses. Whereas parental alienation proceeds on the surface level, an analysis shows that the alienation is often initiated by the economically weaker parent in order to improve his or her monetary post-divorce situation.

The reason why parental alienation does not fully develop its negative consequences in cases of non-consensual divorces in Spain is due to its legal provisions concerning the rights and duties associated with parental authority. There are three effective sanctions towards the parent who initiates alienation in the child against the respective other. First, the judge can extend the visitation regime in favour of the alienated parent upon request of the affected parent. Second, if the alienation continues the law foresees a change of custody in favour of the alienated parent. Third, unlawful interference against the provisions of parental authority are sanctioned by the Criminal Code.

A study of a sample of severe cases of parental alienation brought up to the European Court of Human Rights revealed that national authorities acted negligently when carrying out court judgments. The European Court of Humans Rights made reference to the Convention of the Rights of the Child and granted compensation to all appellants.

In summary it can be said that the Spanish legislation provides sufficient tools to family judges to take counter-measures against parental alienation. According to the judgments of appeal studied in this article the measures taken were effective and served as a threat point to the alienating parent not to exacerbate the problem. 


\section{Table of Statutes and Cases}

Art. 80 Código del Derecho Foral de Aragón (BOE n. 163, de 9.7.2005).

Ley 15/2005, de 8 de julio, por la que se modifican el Código Civil y la Ley de Enjuiciamiento Civil en materia de separación y divorcio (BOE n. 163, de 9.7.2005).

Ley 1/2000, de 7 de enero, de Enjuiciamiento Civil (BOE n. 7, de 8.1.2000, pp. 575-728).

Ley 5/2011, de 1 de abril, de relaciones familiares de los hijos e hijas cuyos progenitores no conviven (BOE n. 98, de 25.4.2011, Sec. I. pp. 41873- 41879).

Ley Orgánica 1/1996, de 15 de enero, de Protección Jurídica del Menor, de modificación parcial del Código Civil y de la Ley de Enjuiciamiento Civil (BOE n. 15, de 17.1.1996).

\section{Spanish Case Law}

\begin{tabular}{|c|c|c|}
\hline Court and date & Reference & Reporting Judge \\
\hline SAP Albacete, 12.12 .2007 & JUR $2008 \backslash 101505$ & Manuel Mateos Rodríguez \\
\hline SAP Madrid, 19.10.2007 & JUR $2008 \backslash 906$ & Eladio Galán Cáceres \\
\hline SAP Cádiz, 5.9.2007 & JUR $2008 \backslash 60961$ & Ramón Romero Navarro \\
\hline SAP Barcelona, 21.11.2007 & JUR $2008 \backslash 30011$ & Juan M. Jiménez de Parga Gastón \\
\hline SAP A Coruña, 31.3.2008 & JUR $2008 \backslash 189828$ & José Luis Seoane Spiegelberg \\
\hline SAP Islas Baleares, 12.3.2008 & JUR $2008 \backslash 332743$ & Juana María Gelabert Ferragut \\
\hline SAP Lugo, 17.12.2007 & JUR $2008 \backslash 81897$ & $\mathrm{M}^{\mathrm{a}}$ Josefa Ruiz Tovar \\
\hline SAP Vizcaya, 27.3.2008 & JUR 2008\130045 & Nekane San Miguel Bergaretxe \\
\hline SAP Toledo, 12.3.2008 & JUR 2011 \189719 & Urbano Suárez Sánchez \\
\hline
\end{tabular}

\section{European Court of Human Rights}

\begin{tabular}{lll}
\hline Date & Reference & Case \\
\hline 11.1 .2011 & C- 5/2011 & Bordeianu v. Moldavia \\
\hline 2.9 .2010 & C- 91/2010 & Mincheva v. Bulgaria \\
\hline 2.11 .2010 & C- 360648/2010 & Piazzi v. Italy \\
\hline
\end{tabular}

\section{References}

J. M. Aguilar CuencA, (2005), “El uso de los hijos en los procesos de separación: el síndrome de alienación parental", Revista de Derecho de Familia, n. 29, pp. 71-79.

L. Alascio CARRASCO, (2008), "El síndrome de alienación parental. A propósito de la SJPI n ${ }^{\circ} 4$ de Manresa, de 14 de junio de 2007", InDret, n. 1, pp. 1-8. 
P. AmAto, (1994), "Life-Span Adjustment of Children to Their Parents' Divorce", The Future of Children, Children and Divorce, Vol. 4, n. 1, pp. 143-164.

P. Amato, and J. GiLbReth, (1999), “Nonresident fathers and children's well-being: A metaanalysis", Journal of Marriage and the Family, Vol. 61, pp. 557-573.

P. AMATO, and B. KeITH, (1991), "Parental divorce and the well-being of children: A metaanalysis", Psychological Bulletin, Vol. 110, pp. 26-46.

W. Aquilino, (2006), "The Noncustodial Father-Child Relationship From Adolescence Into Young Adulthood", Journal of Marriage and Family, Vol. 68, pp. 929-946.

J. ARDITTI, (1992), "Factors related to custody, visitation, and child support for divorced fathers: An exploratory analysis", Journal of Divorce and Remarriage, Vol. 17, n. 3, 4 and pp. 23-42.

A.BAKER, (2005), "The Long-Term Effects of Parental Alienation on Adult Children: A Qualitative Research Study", The American Journal of Family Therapy, Vol. 33, pp. 289-302.

R. BAUSERMAN, (2002), “Child Adjustment in Joint-Custody Versus Sole-Custody Arrangements: A Meta-Analytic Review", Journal of Family Psychology, Vol. 16, n. 1, pp. 91-102.

R. Bercovitz Rodríguez-CANo, (ed.) (2006), Comentarios al Código Civil, Thomson Aranzadi, Navarra.

M. Bermúdez TAPIA, (2009), "El síndrome de alienación parental”, Revista de Derecho de Familia, n. 44 , pp. $255-284$.

W.BERNET et al. (2010), "Parental alienation, DSM-V, and ICD-11", The American Journal of Family Therapy, Vol. 38, n. 2, pp. 76-187.

B. BROOKS-Gordon and M. FreEMAN, (2006), Law and Psychology, Oxford University Press.

A. CARrasco Perera (2005), "Sobre custodia compartida”, Actualidad Jurídica Aranzadi, n. 648 p.3.

J. CORSI, (2007), “El síndrome de alienación parental o el peligro que entrañan las teorías pseudocientíficas como base de las decisiones judiciales", Themis: revista jurídica de igualdad de género, n. 1, pp. 73-77.

A.Escudero; L.Aguilar, and J. De la CruZ, (2008), “La lógica del Síndrome de Alienación Parental de Gardner (SAP): «terapia de la amenaza»", Revista Asociación Esp. Neuropsiquiatría, Vol. 28, n. 102, pp. 283-305. 
J. FERNÁNDEZ CAMPOS, (2008), “Sentencia de 27 de junio de 2007: Derecho de uso sobre vivienda familiar y partición ganancial”, Cuadernos Civitas de Jurisprudencia Civil, n. 77, pp. 585-594.

A. Freud, (1993), The Ego and the Mechanisms of Defence, Karnac Books, London.

W. FTHENAKIS, (1998), "Family Transitions and Quality in Early Childhood Education", European Early Childhood Education Research Journal, Vol. 6, n. 1ff.

M. Gaffal, (2010), Psychosocial and Legal Perspectives of Marital Breakdown. With Special Emphasis on Spain, Springer: Heidelberg.

R. GARDNer, (1986), The Parental Alienation Syndrome. A Guide for Mental Health and Legal Professionals, Creative Therpaeutics, Inc., New Jersey.

--- (1994), "Legal and Psychotherapeutic Approaches to the Three Types of Parental Alienation Syndrome Families. When Psychiatry and Law Join Forces", Court Review, Vol. 28, n. 1, pp. 14-21.

--- (2002), Das elterliche Entfremdungssyndrom. (Parental Alienation Syndrome). Anregungen für gerichtliche Sorge- und Umgangsregelungen. Eine empirische Untersuchung, Verlag für Wissenschaft und Bildung, Berlin.

P. Gómez MEgAN, (2008), “Síndrome de alienación parental”, Revista de Derecho de Familia, n. 38, pp. 63-78.

C. Guilarte Martín-Calero, (2005), "Comentarios del nuevo artículo 92 del Código Civil”, in: V. Guilarte Gutiérrez (ed.), Comentarios a la reforma de la separación y el divorcio (Ley 15/2005, de 8 de julio), Editorial Lex Nova, Valladolid, pp. 113-179.

M.Hendrick, (1994), “The Parental Alienation Syndrome: An Analysis of Sixteen Selected Cases", Journal of Divorce \& Remarriage, Vol. 21, pp. 21-38.

A.JARNE ESPARCiA, and M. ARCH MARÍn, (2009), "DSM, salud mental y síndrome de alineación parental", Papeles del Psicólogo, Vol. 30, n. 1, pp. 86-91.

J. JunNE; M.HedRICK, (1994), "The Parental Alienation Syndrome: An Analysis of Sixteen Selected Cases", Journal of Divorce \& Remarriage, Vol. 21, pp. 21-38.

J. Montero Aroca, (2002), El Convenio Regulador el la Separación y en el Divorcio. La aplicación práctica del artículo 90 del Código Civil, Tirant Lo Blanch, Valencia.

A. NAPP-PETERS, (1995), Familien nach der Scheidung, Kunstmann, Munich.

M. KARPF, and I. SHATZ, (2005), "Divorce Is Over - What about the Kids?" American Journal of Family Law, Vol. 19, n. 1, pp. 7-11. 
R. KELLY; L.REDENBACH, and W.RINAMON, (2005), "Determinants of custody arrangements in a national sample", American Journal of Family Law, Vol. 19, pp. 25-43.

C. RIECK, (1992), Spieltheorie. Eine Einführung, Eschborn: Christian Rieck Verlag.

L. Rodríguez Ramos, (ed.) (2007), Código Penal. Comentado y con Jurisprudencia, Wolters Kluwer, Madrid.

I. SÁNCHEZ IGLESIAS, (2006), “Infancia y adolescencia ante la separación de los padres: efecto mediador de los Puntos de Encuentro Familiares", Revista de Estudios de Juventud, 73, pp. 93-106.

SAN Segundo MANUel, T. (2011), "Maltrato y separación: Repercusiones en los hijos", en C. VILlagrasa AlCAIDE (coord.), Manual de Derecho de familia, Bosch, pp.541-582.

J. SARIEGO MORILlO, (2009), "Reflexiones sobre el síndrome de alienación parental", Revista de Derecho de Familia, n. 44, pp. 289-296.

C.SEGURA; MJ. GIL, and M.A. SEPÚlVEDA, (2006), "El síndrome de alienación parental: una forma de maltrato infantil. The parental alienation syndrome: a way of mistreatment on children", Cuadernos de Medicina Forense, Vol. 12, n. 43/44, pp. 117-128.

C. SumMERS, and D.Summers, (2006), "Unadulterated Arrogance: Autopsy of the Narcissistic Parental Alienator", The American Journal of Family Therapy, Vol. 34, pp. 399-428.

A. Tejedor Huerta, (2007), "Intervención ante el síndrome de alienación parental”, Anuario de Psicología Jurídica, Vol. 17, pp. 79-89.

R. THOMPSON, (1994), "The Role of the Father After Divorce", Children and Divorce, Vol. 4, n. 1, pp. 216-235.

D.VAssiliou and G. CARTwright, (2001), "The Lost Parents' Perspective on Parental Alienation Syndrome", The American Journal of Family Therapy, Vol. 29, pp. 181-191.

G.Vives MARTíNEZ, (2007), “A vueltas con el Síndrome de Alienación Parental: ¿problema, patología, realidad? Luces, sombras y mitos al respecto" Economist $\mathcal{E}$ Jurist, Vol. 15, n. 115, pp. 116-124.

--- (2007), “Custodia compartida, valoración de la prueba y victimización de los menores: una visión objetiva desde la Magistratura y la experiencia", Economist $\mathcal{E}$ Jurist, Vol. 15, n. 113, pp. 8898. 
M.WALSH and J.BONE, (1997), "Parental Alienation Syndrome, An Age-old Custody Problem", The Florida Bar Journal, Vol. LXXI, n. 6, pp. 93-96.

U. WARTNER et al. (1994), "Attachment patterns at age six in South Germany: Predictability from infancy and implications for preschool behaviour", Child Development, Vol. 65, pp. 1014-1027. 